\title{
Hedgehog/GLI signaling in tumor immunity - new therapeutic opportunities and clinical implications
}

\author{
Sandra Grund-Gröschke, Georg Stockmaier and Fritz Aberger * (D)
}

\begin{abstract}
Uncontrolled activation of the Hedgehog/Glioma-associated oncogene (HH/GLI) pathway is a potent oncogenic driver signal promoting numerous cancer hallmarks such as proliferation, survival, angiogenesis, metastasis and metabolic rewiring. Several HH pathway inhibitors have already been approved for medical therapy of advanced and metastatic basal cell carcinoma and acute myeloid leukemia with partially impressive therapeutic activity. However, de novo and acquired resistance as well as severe side effects and unexplained lack of therapeutic efficacy are major challenges that urgently call for improved treatment options with more durable responses. The recent breakthroughs in cancer immunotherapy have changed our current understanding of targeted therapy and opened up promising therapeutic opportunities including combinations of selective cancer pathway and immune checkpoint inhibitors. Although $\mathrm{HH} / \mathrm{GLI}$ signaling has been intensely studied with respect to the classical hallmarks of cancer, its role in the modulation of the anti-tumoral immune response has only become evident in recent studies. These have uncovered HH/GLI regulated immunosuppressive mechanisms such as enhanced regulatory Tcell formation and production of immunosuppressive cytokines. In light of these exciting novel data on oncogenic $\mathrm{HH} / \mathrm{GLI}$ signaling in immune cross-talk and modulation, we summarize and connect in this review the existing knowledge from different $\mathrm{HH}$-related cancers and chronic inflammatory diseases. This is to provide a basis for the investigation and evaluation of novel treatments combining immunotherapeutic strategies with approved as well as next-generation HH/GLI inhibitors. Further, we also critically discuss recent studies demonstrating a possible negative impact of current $\mathrm{HH} / \mathrm{GL}$ pathway inhibitors on the anti-tumoral immune response, which may explain some of the disappointing results of several oncological trials with anti-HH drugs.
\end{abstract}

Keywords: Oncogenic Hedgehog/GLI signaling, Tumor microenvironment, Cancer immunotherapy, Immunosuppression, Immune evasion, Immune checkpoint inhibitors, Chronic inflammation, Combination therapy

\section{Background}

Since its discovery in the 1980s by Christiane NüssleinVollhard and Eric Wieschaus the Hedgehog/Glioma-associated oncogene (HH/GLI) signaling pathway has been studied in great detail [1]. HH/GLI signaling can orchestrate several central developmental processes, including pattern and limb formation in the embryonic development or cell proliferation and differentiation. In the adult organisms the pathway is mostly inactive but reactivated during tissue homeostasis and regeneration as

\footnotetext{
* Correspondence: fritz.aberger@sbg.ac.at

Department of Biosciences, Cancer Cluster Salzburg, University of Salzburg, Hellbrunner Strasse, 34, 5020 Salzburg, Austria
}

well as in the process of wound healing by controlling stem cell activation and self-renewal.

Unlike most classical signaling cascades, HH/GLI signaling is actively repressed in the absence of ligand and initiated by binding of $\mathrm{HH}$ ligand protein to its receptor and pathway repressor Patched (PTCH1). In addition to mere receptor binding, this step also apparently inactivates the catalytic activity of PTCH1, thereby changing the cholesterol composition within the leaflets of the lipid bilayer of the cell membrane close to the primary cilium, an antenna-like compartment critical for the coordination of HH/GLI signal strength and duration. HH ligand binding relieves the repressive function of PTCH1, thereby allowing the translocation of the G-protein coupled receptor-

(c) The Author(s). 2019 Open Access This article is distributed under the terms of the Creative Commons Attribution 4.0 International License (http://creativecommons.org/licenses/by/4.0/), which permits unrestricted use, distribution, and 
like protein Smoothened (SMO) into the primary cilium, where its activation results in the conversion of transcriptionally repressive GLI zinc-finger transcription factors into transcriptional activator forms [2-11].

While the exquisite and precise quantitative control of HH/GLI signaling in space and time is mandatory for normal development and health of mammals, irreversible and uncontrolled activation of the HH/GLI pathway is detrimental and has been shown to cause or contribute to the development of a variety of cancer entities. For instance, HH/GLI represents a key molecular driver signal in basal cell carcinoma (BCC), medulloblastoma (MB) and rhabdomyosarcoma and has been implicated in the malignant progression of for instance gastrointestinal, pancreatic, ovarian, breast, prostate and lung cancers, melanoma, glioma, and several leukemia including chronic lymphocytic leukemia (CLL), chronic myeloid leukemia (CML), diffuse large B-cell lymphoma (DLBCL) and acute myeloid leukemia (AML) (for reviews see $[2,4,12-22]$ and references therein).

In light of the critical role of HH/GLI in various malignancies and oncogenic processes, several clinically suitable $\mathrm{HH}$ pathway inhibitors have been successfully developed. This is reflected by the approval of the first SMO inhibitor vismodegib (GDC-0449, ERIVEDGE ${ }^{\mathrm{mm}}$ ) in 2012 for the treatment of locally advanced and metastatic BCC [2327], followed by the approval of sonidegib (LDE225, $\mathrm{ODOMZO}^{\mathrm{m}}$ ) after having shown therapeutic efficacy in BCC patients [28-31]. Only recently, the SMO antagonist glasdegib (PF-04449913, DAURISMO ${ }^{\mathrm{m}}$ ) has been approved in combination with low-dose chemotherapy for the treatment of acute myeloid leukemia patients after clinical studies have shown nearly a doubling of the overall survival of AML patients if glasdegib is included in the low-dose chemotherapy regimen [32, 33]. Furthermore, the clinically approved chemotherapeutic agent arsenic trioxide (ATO) (TRISENOX ${ }^{\mathrm{Tm}}$ ) has been identified as potent inhibitor of GLI activity, adding another promising compound to the growing drug armamentarium against $\mathrm{HH}$-driven cancers $[34,35]$.

Despite the impressive therapeutic efficacy of $\mathrm{HH}$ pathway inhibitors, de novo and acquired drug resistance as well as severe side effects are major limitations to the successful use of SMO antagonists [29, 36-38]. Of note, $50 \%$ of the $\mathrm{BCC}$ patients that show resistance to the SMO inhibitors express mutant SMO variants and show maintained high-level HH/GLI pathway activity. Mutations occur either directly in the ligand binding pocket (LBP) of SMO or outside the LBP in pivotal regions of the transmembrane-helices that ensure receptor auto-inhibition. Further resistance mechanisms comprise GLI2 gene amplifications, loss of the GLI repressor Suppressor of Fused (SUFU), or a signaling shift towards protein kinase $\mathrm{C}$ (PKC), phosphatidyl inositol-3 kinase
(PI3K) and/or mitogen activated protein kinase (MAPK) activity [39-44].

Such therapeutic challenges call for improved treatment strategies for the patients' benefit. The recent breakthroughs in cancer immunology and immunotherapy have highlighted the necessity for a precise understanding of the immune-modulatory function of oncogenic signaling pathways and their actual role in tumor immunity. Such precise and context-dependent knowledge is mandatory for the development of rational combination treatments targeting for instance oncogenic and immunosuppressive signals. Along the same line, it is equally important to understand the role of HH/GLI in tumor immunity in both the tumor itself as well as in the immune microenvironment of the cancer to guide and select the most efficient drug combination with more durable responses and increased response rates.

As for HH/GLI signaling, recent studies have linked HH/GLI pathway activation with concomitant antiinflammatory signals $[45,46]$ and revealed a significant downregulation of the pathway in a set of chronic inflammatory diseases such as inflammatory bowel disease [47], colitis [48, 49] and Helicobacter pylori associated gastric inflammation $[21,50]$. Notably, there is also increasing evidence, showing that oncogenic HH/GLI signaling regulates immunosuppressive mechanisms such as enhanced regulatory T-cell (Treg) formation and production of immunosuppressive cytokines, which can open new avenues for combination treatments and immunotherapy [49, 51-56].

In light of these recent insights, we here summarize and reconcile the existing knowledge from different $\mathrm{HH} /$ GLI-related cancers and chronic inflammatory diseases and discuss the relevance of HH/GLI signaling in modulating the immune response, which should provide a basis for the future evaluation of novel treatment options and may also help explaining the failure of $\mathrm{HH}$ pathway inhibitors in several clinical trials [57].

\section{$\mathrm{HH}$ signaling and tumor immunity}

The adaptive as well as innate immune system forms a highly proficient immune surveillance machinery that recognizes and destroys genetically altered cells to prevent the development of malignant diseases. Cancer development driven by genetic and epigenetic evolution and clonal selection, therefore, involves a plethora of molecular mechanisms that eventually lead to the suppression of the anti-tumoral response and immune evasion of malignant cells, respectively [58]. Notably, the administration of for instance immune checkpoint inhibitors that efficiently re-instate the anti-tumoral immune response have shown unprecedented therapeutic efficacy in several metastatic diseases [59-61], suggesting that rational combination treatments targeting oncogenic $\mathrm{HH}$ / 
GLI and immunosuppressive mechanisms may synergistically improve the efficacy and durability of the therapeutic response of patients suffering from HH/GLIassociated cancers. In the following chapter we summarize recent findings about the implication of $\mathrm{HH} /$ GLI signaling in the context of immunosuppression and immune evasion (summarized in Fig. 1).

Mutational activation of HH/GLI signaling plays a causal role in the development and growth of BCC. Intriguingly, systematic genome sequencing of several hundreds of sporadic human BCC revealed a surprisingly high mutational burden with an average of 65 mutations per megabase [62]. Although these sequencing data have not yet been analyzed with respect to the immunogenicity of the mutations, it is highly likely that BCC express tumor-specific neoantigens rendering $\mathrm{BCC}$ lesions immunogenic. We, therefore, hypothesize that HH/GLI signaling - in addition to tumor-intrinsic proliferative and pro-survival cues - also induces an immunosuppressive microenvironment to hamper an effective anti-tumoral immune response.

First evidence for such immunosuppressive mechanisms in BCC came from studies of murine BCC models showing that transforming growth factor beta (TGF $\beta$ ) secreted by oncogenic SMO-expressing keratinocytes is able to reduce the number of effector lymphocytes in the tumor tissue. In addition, TGF $\beta$ signaling in bone marrow cells of BCC mice appears to support tumor growth by recruiting immunosuppressive myeloid derived suppressor cells (MDSC) to $\mathrm{BCC}$ lesions in a $\mathrm{C}-\mathrm{C}$ motif chemokine ligand 2 (CCL2) dependent manner (Fig. 1). In agreement, pharmacologic inhibition of the CCL2 receptor expressed by MDSCs not only interfered with the recruitment of these cells but also reduced tumor growth. However, the detailed anti-tumoral mechanisms in response to CCL2 receptor inhibition remain elusive [53, 63].

Further evidence that $\mathrm{HH}$ signaling induces immunosuppressive mechanisms such as MDSC recruitment and M2 polarization of macrophages was provided by the analysis of an immunocompetent breast cancer xenograft mouse model. Treatment of engrafted mice with the SMO inhibitor vismodegib reduced immunosuppressive immune cell populations such as MDSCs, M2 macrophages and Treg cells in the tumor lesions, while it increased the number of cytotoxic $\mathrm{CD}^{+}{ }^{+} \mathrm{T}$-cells and $\mathrm{M} 1$ macrophages, resulting in less metastasis. Notably, macrophage depletion in combination with $\mathrm{HH}$ pathway inhibition further improved the therapeutic effect of $\mathrm{HH}$ blockade alone [64].

Analysis of human UV-exposed facial BCC revealed that Treg cells accumulate in high amount within intraand peritumoral regions. This is accompanied by a strong increase of immunosuppressive TGF $\beta$ in the peritumoral skin [54]. In this context, it is intriguing to mention that the $\mathrm{HH}$ effector and zinc finger transcription factor GLI2 can directly activate the expression of TGF $\beta$ in human Treg cells [55] (Fig. 1). This immune modulatory role of HH/GLI signaling in T-cells is further underlined by a study showing that GLI2 can

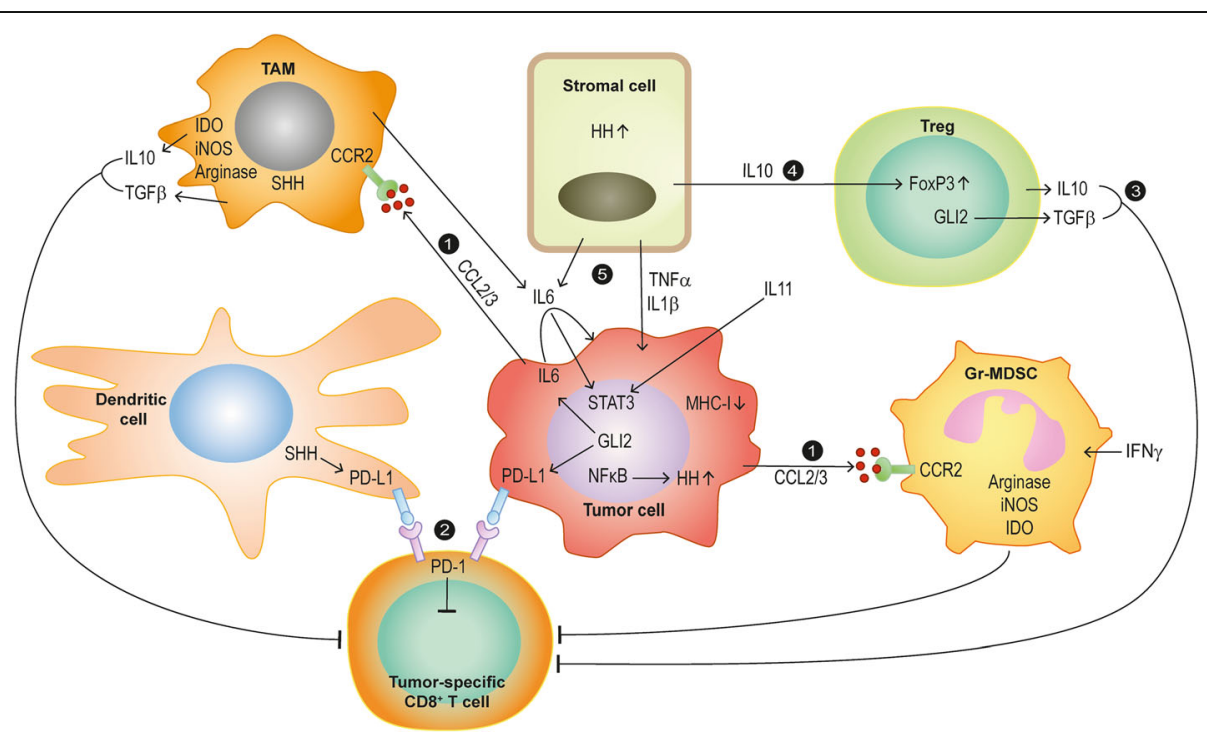

Fig. 1 Mechanisms of immune modulation by HH/GLI signaling in cancer and inflammation. 1) Cancer cells release CCL2/3 in response to oncogenic HH/GLI signaling, thereby recruiting TAMs and immunosuppressive MDSCs. 2) HH/GLI-induced PD-L1 expression in cancer and dendritic cells inhibits tumor specific cytotoxic T-cells via binding to PD-1. 3) GLI2 drives production of immunosuppressive cytokines and growth factors (IL10 and TGF $\beta$ ), which results in the inactivation of tumor specific $C D 8^{+} \mathrm{T}$-cells. 4) HH/GLI-induced IL10 from stromal cells promotes FoxP3 expression in regulatory Tcells. 5) Pro-inflammatory signals such as IL6/STAT3 interact with HH/GLI signaling; HH/GLI-induced autocrine IL6 signaling and/or pro-inflammatory IL6 from TAM and stromal cells activate STAT3 signaling in cancer cells, thereby promoting malignant growth 
attenuate $\mathrm{T}$-cell activation and function by altering gene expression profiles in T-cells. GLI2 activation results in impaired TCR-induced calcium influx and differential expression of major components of the TCR signaling pathway such as nuclear factor kappa $B(\mathrm{NFKB})$ and activator protein-1 (AP-1) factors [65]. Furthermore, HH/ GLI signaling is able to polarize Th2 differentiation of $\mathrm{T}$-cells by inducing interleukin-4 (IL4) production, thereby promoting allergic responses and reducing cytotoxic $\mathrm{T}$-cell function in the context of tumor immunity $[66,67]$. In addition to $\mathrm{T}$-cell polarization, activation of $\mathrm{HH} / \mathrm{GLI}$ in naïve $\mathrm{CD} 4^{+} \mathrm{T}$-cells in the context of atopic dermatitis development has been shown to induce the differentiation of immunosuppressive Treg cells expressing elevated FOXP3 and TGF $\beta$ levels [68] (Fig. 1). Despite convincing evidence for a cell-autonomous role of HH/GLI in Treg formation, it remains unclear of whether T-cell intrinsic activation of HH/GLI also plays an immunosuppressive role in the microenvironment of $\mathrm{HH}$-driven cancers such as BCC.

Further evidence for a role of HH/GLI in Treg formation comes from the analysis of patients infected with Mycobacterium tuberculosis. In this study, mycobacteriainfected human DCs upregulated SHH signaling, which in turn was able to induce programmed death ligand 1 (PD-L1) expression (Fig. 1). This resulted in Treg formation and expansion, thereby favoring immune evasion of the pathogen [51]. In addition to this, using humanderived gastric cancer organoids it was demonstrated that GANT-61 could reduce PD-L1 expression and tumor cell proliferation in vitro and in vivo. Of note, treatment with anti-PD-L1 antibodies induced apoptosis of tumor cells derived from GLI2-expressing mouse organoids. The results identify GLI2 as tumor-cell intrinsic regulator of PD-L1 expression in gastric cancer, promoting cancer growth via suppression of antitumoral responses [56].

Aside from the effects of HH/GLI on immunosuppression in malignant settings, Sonic $\mathrm{HH}(\mathrm{SHH})$-induced Treg formation can also constrain inflammation driven diseases $[49,52]$. For instance, in colitis, activation of HH/GLI signaling dampens the inflammation, thereby preventing inflammatory intestinal damage. In this context Lee et al. showed increased interleukin-10 (Il10) expression by Gli1positive stromal cells upon chemical $\mathrm{HH}$ pathway activation together with an increased number of Treg cells [49] (Fig. 1). A similar mechanism was discovered in a mouse acute pancreatitis model, where autocrine Shh signaling induced Il10 production resulting in reduced inflammation [52]. Notably, inhibition of $\mathrm{Hh} / \mathrm{Gli}$ signaling worsened the progression of the inflammatory disease and promoted colitis-associated cancer development $[49,52]$. It is, therefore, conceivable that pro-inflammatory responses to SMO-targeting contributed to the failure of colon cancer trials, where drug targeting of $\mathrm{HH}$ signaling accelerated cancer progression, which forced the termination of the clinical studies.

The immunosuppressive activity of HH/GLI in the intestine is further supported by a study of Westendrop et al. showing that epithelial-derived Indian hedgehog (Ihh) is able to maintain immune tolerance in the intestine. Loss of Ihh from the intestinal epithelium led to increased expression of inflammation-related genes and an influx of immune cells. Mechanistically, Ihh can inhibit the release of the chemokine CXCL12 by fibroblasts and thereby, reduce the recruitment of immune cells. In agreement with its immunosuppressive function, loss of Ihh resulted in increased colitis [69].

In the context of Helicobacter pylori-induced gastric inflammation and carcinogenesis, the bacterial infection has been shown to induce $\mathrm{SHH}$ signaling via activation of NFkB signaling [70] (Fig. 1). During chronic gastric inflammation, $\mathrm{HH} / \mathrm{GLI}$ signaling can support polarization of myeloid cells towards granulocytic-MDSCs (GrMDSCs) (Fig. 1) [71, 72]. SHH secreted from parietal cells has been shown to attract Schlafen 4 (SLFN4)-positive myeloid cells from the bone marrow. SLFN4-positive myeloid cells can further polarize by IFN $\alpha$ to GrMDSCs, which then are able to inhibit tumor infiltrating lymphocytes, favoring neoplastic transformation and cancer growth [21, 71, 73]. Interestingly, El-Zaatari et al. provided additional evidence for a critical role of HH/GLI in immune suppression and malignant transformation, since Gli1 deletion in mice prevented both Helicobacter pylori-induced expansion of MDSCs and metaplasia [50].

As already mentioned above in the context of $\mathrm{HH} /$ GLI-dependent Treg formation, HH/GLI is likely to cause immunosuppression also by inducing the expression of immune checkpoint molecules. For instance, in BCC with tumoral PD-L1 expression, two patients with metastatic disease responded well to $\alpha \mathrm{PD}-1$ single treatment with nivolumab or pembrolizumab $[74,75]$. Lipson et al. further analyzed $40 \mathrm{BCC}$ specimens and found PDL1 expression on tumor cells to be upregulated in $22 \%$ of all analyzed samples with an additional $82 \%$ of specimen demonstrating PD-L1 expression on tumor infiltrating lymphocytes and associated macrophages (Fig. 1) [76]. Intriguingly, PD-L1 upregulation was also observed in some medulloblastoma patients, were the highest PDL1 expression was found in a patient with SHH subtype MB [77]. Together with the results of a study with GLI2-expressing PD-L1-positive gastric organoids [56], these data together suggest a direct regulatory function of $\mathrm{HH} / \mathrm{GLI}$ in the control of immune checkpoint expression.

Finally, another mechanism how cancer cells can evade the immune system is by downregulating MHC-I expression, whereby tumor antigen-specific $\mathrm{T}$-cells are 
then no longer capable of recognizing and destroying these abnormal cells [58, 78]. Recently, inhibition of the $\mathrm{HH}$ pathway in BCC patients with the SMO Inhibitors vismodegib or sonidegib led to increased levels of MHCI expression on tumor cells together with an increase of $\mathrm{CD} 4$ and $\mathrm{CD} 8$ positive $\mathrm{T}$-cells in the peri- and intratumoral regions. These findings indicate that MHC-I downregulation occurs in $\mathrm{HH}$-driven $\mathrm{BCC}$ to evade the recognition and destruction by the immune system [79].

In summary, there is increasing evidence from multiple studies that demonstrate an important and multifacetted immune-modulatory role of HH/GLI in various inflammatory and malignant settings. Active HH/GLI signaling can induce an immunosuppressive microenvironment via multiple routes, including the activation of immunosuppressive cytokines, upregulation of immune checkpoints, or expansion and chemotactic recruitment of immunosuppressive cells including Treg and MDSCs. The immune-modulatory activity of HH/GLI in cancer settings thus opens up new therapeutic avenues for future treatment strategies of $\mathrm{HH} / \mathrm{GLI}$ associated cancers.

\section{Oncogenic HH/GLI signaling and inflammation}

The immune system plays a decisive and at least dual role in the initiation and progression of malignant diseases. While the immune system is critical for preventing and/or fighting cancer via processes referred to as immune surveillance and anti-tumoral immunity, the persistent and inappropriate activation of the immune system manifested as (chronic) inflammation has been identified as potent promoter and enabler of malignant development $[80,81]$. The persistent production of pro-inflammatory cytokines such as IL6, tumor necrosis factor (TNF) and IL1 within the tumor and its microenvironment plays a key role in mediating the tumor-promoting effect of inflammation (reviewed in [58, 82, 83]).

Several recent studies have provided evidence for reciprocal regulatory interactions of HH/GLI signaling and proinflammatory cues during malignant development, including tumor-promoting synergistic signal integration processes. For instance, in pancreatic cancer, stromal HH/GLI signaling has been shown to induce IL6 expression (Fig. 1), which in turn results in paracrine activation of STAT3 in the tumor cell compartment, thereby supporting cancer growth and survival [84]. Another study of pancreatic cancer provided evidence for HH/GLI activation in response to inflammatory TNF and IL1 signaling. Mechanistically, the activation of $\mathrm{NFK} B$ by pro-inflammatory signals can induce the expression of GLI1 in a HH-dependent and non-canonical, HH/SMOindependent manner [85]. Similarly, Nakashima et al. investigated the interplay of $\mathrm{NFKB}$ and $\mathrm{HH}$ pathway activation in human pancreatic cancer, linking IL1, TNF and LPS mediated induction of $\mathrm{NFkB}$ signaling with elevated $\mathrm{SHH}$ levels and accelerated cancer cell proliferation (Fig. 1) [86].
In BCC, the interaction of HH/GLI and proinflammatory IL6/signal transducer and activator of transcription-3 (STAT3) signaling synergistically regulates common GLI-STAT3 target genes and promotes cancer proliferation (Fig. 1) [87, 88]. Furthermore, aberrant regulation of HH/GLI signaling has been implicated in Helicobacter induced stomach cancer, where GLI1 function in myeloid cells recruited to the metaplastic area is required for a pro-inflammatory signaling network including IL1 in the myeloid and as a consequence IL6/STAT3 expression in the epithelial compartment [50].

These findings altogether suggest an intricate interplay of $\mathrm{HH} / \mathrm{GLI}$ signaling and pro-inflammatory effectors generating a tumor-promoting environment and it will be pivotal to decipher these reciprocal interactions in a cancer entity- and context-dependent manner for the development of future combination therapies interfering with $\mathrm{HH} / \mathrm{GLI}$ itself together with cooperative proinflammatory pathways (Fig. 2).

\section{Conclusions}

Although the field of tumor immunology in the context of oncogenic $\mathrm{HH} / \mathrm{GLI}$ signaling is relatively young, it has already become evident that HH/GLI signaling exerts complex and diverse effects on the immune microenvironment of malignant and non-malignant tissues. Dysregulation of $\mathrm{HH} / \mathrm{GLI}$ signaling plays fundamental yet distinct roles both in cancer and chronic inflammatory diseases. For instance, in colitis or pancreatitis, lack of $\mathrm{HH}$ expression has been shown to foster chronic inflammation, which is likely to promote tumor formation [45, $49,52,69]$. By contrast, in several cancer entities, aberrantly activated $\mathrm{HH} / \mathrm{GLI}$ signaling drives tumor proliferation and growth, while simultaneously dampening inflammation and favoring immunosuppression [53, 54, 64]. Understanding the molecular rationale of how deregulation of the HH/GLI signaling axis precisely alters anti-tumor immunity and tumor-promoting inflammation will support the development of more sophisticated tumor therapies.

Given the immunosuppressive function of HH/GLI, HH antagonists may synergize with immune checkpoint blockers such as anti-PD-1 antibodies in fighting cancer. Notably, single case studies with BCC patients receiving nivolumab or pembrolizumab (two clinically approved anti-PD-1 antibodies) have already yielded promising results, suggesting that the use of immune checkpoint inhibitors can provide a therapeutic benefit in HH/GLI-driven non-melanoma skin cancer $[74,76,89,90]$. The outcome of recent and ongoing clinical trials with immune checkpoint inhibitors for the treatment of metastatic or unresectable BCC alone or in combination with $\mathrm{HH} / \mathrm{SMO}$ inhibitors will inform about whether immunotherapy or 


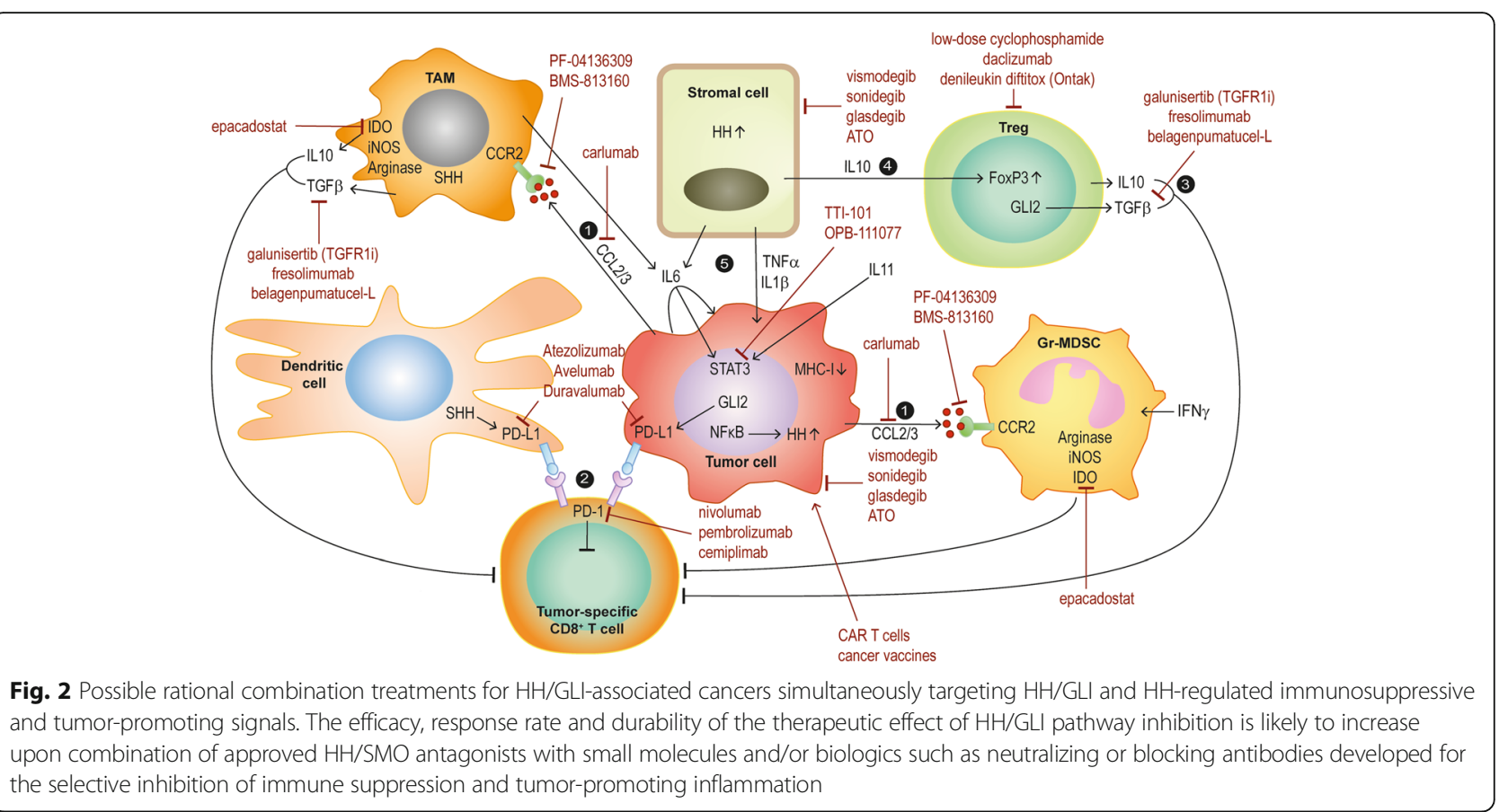

combinatorial treatments can increase the efficacy and durability of the response of BCC patients (see https:// www.clinicaltrials.gov/ trials identifiers: NCT03132636; NCT03521830; NCT02690948). The results of these trials will also have important consequences for the treatment of other $\mathrm{HH}$-associated cancer entities [85, 91].

The patients' response to immune checkpoint inhibitors correlates with the tumor mutational burden [92]. Given the extraordinary high mutation rate of BCC [62], chances are high that rational combination treatments involving $\mathrm{HH}$ pathway inhibitors together with immunotherapeutics (summarized in Fig. 2) will increase the efficacy of current medical therapies of unresectable advanced and metastatic BCC, and possibly also of other $\mathrm{HH}$-associated malignancies with high medical need. In this context it is noteworthy that the immunemodulatory drug imiquimod is already successfully used for the treatment of superficial BCC $[58,93]$ by boosting T-cell effector function, although there are other reports suggesting an additional therapeutic role of imiquimod such as by directly blunting oncogenic HH/GLI via activation of adenosine receptor/protein kinase A (PKA) signaling and by activating tumor-killing plasmacytoid dendritic cells [94-97].

Despite the promising outlook for the use of $\mathrm{HH}$ pathway inhibitors in combination with immunotherapy, there are also challenges and concerns for the use of $\mathrm{HH}$ inhibitors as immune modulators. For instance, a study of de la Roche and colleagues has unraveled a role of SMO in the immunological synapse during T-cell activation. Administration of SMO inhibitors led to the functional disruption of the immunological synapse and consequently, to the loss of T-cell effector activity [98]. Although it is unclear whether the administration of SMO inhibitors impedes cytotoxic T-cell functions in patients - which could to some extent explain the failure of several clinical trials with SMO inhibitors $[57,99]$ - the possible negative impact of $\mathrm{HH}$ targeting on the antitumoral response needs to be considered in future studies, particularly in those that involve immune checkpoint inhibitors. A better understanding of the effect of $\mathrm{HH} / \mathrm{GLI}$ pathway modulators and cancer drugs on the immune response is therefore pivotal and will pave the way towards the next generation of combination therapies involving $\mathrm{HH} / \mathrm{GLI}$ inhibitors and immunotherapeutic drugs.

\section{Abbreviations}

AML: Acute myeloid leukemia; AP-1: Activator protein-1; BCC: Basal cell carcinoma; CCL2: C-C motif chemokine ligand 2; CLL: Chronic lymphocytic leukemia; CML: Chronic myeloid leukemia; DLBCL: Diffuse large B-cell lymphoma; GLI: Glioma-associated oncogene; HH: Hedgehog; IFNY: Interferon gamma; IHH: Indian Hedgehog; IL1: Interleukin-1; IL10: Interleukin-10; IL6: Interleukin-6; MAPK: Mitogen activated protein kinase; MDSC: Myeloid derived suppressor cell; NFKB: Nuclear factor kappa B; PD-1: Programmed death-1; PD-L1: Programmed death ligand-1; PI3K: Phosphoinositide 3 kinase; PKC : Protein kinase C; PTCH1: Patched-1; SHH: Sonic Hedgehog;

SLFN4: Schlafen-4; SMO: Smoothened; STAT3: Signal transducer and activator of transcription 3; SUFU: Suppressor of Fused; TAM: Tumor associated macrophages; TNF: Tumor necrosis factor; Treg: Regulatory T-cells

\section{Acknowledgements}

We are thankful to Dominik Elmer and Drs Jutta Horejs-Hoeck and Iris Gratz for frequent discussions and scientific input relevant to the immunological sections of the review, and to all other members of the Aberger group for continuous support. 


\section{Authors' contributions}

SG-G, GS and FA search and studied the relevant literature and wrote the review. FA conceived the content of the manuscript and figures; SG-G designed the figures. All authors read and approved the final manuscript.

\section{Funding}

Work of the authors has been supported by the Austrian Science Fund FWF (projects W1213 and P25629-B19 to FA), the priority program Allergy-CancerBionano Center of the University of Salzburg, and the Cancer Cluster Salzburg supported by the County of Salzburg.

\section{Availability of data and materials}

Not applicable.

Ethics approval and consent to participate

Not applicable.

\section{Consent for publication}

Not applicable.

\section{Competing interests}

The authors declare that they have no competing interests.

Received: 21 August 2019 Accepted: 10 October 2019

Published online: 26 December 2019

\section{References}

1. Nusslein-Volhard C, Wieschaus E. Mutations affecting segment number and polarity in Drosophila. Nature. 1980;287:795-801.

2. Aberger F, Ruiz IAA. Context-dependent signal integration by the GLI code: the oncogenic load, pathways, modifiers and implications for cancer therapy. Semin Cell Dev Biol. 2014;33:93-104. https://doi.org/10.1016/j. semcdb.2014.05.003.

3. Kasper M, Regl G, Frischauf AM, Aberger F. GLI transcription factors: mediators of oncogenic Hedgehog signalling. Eur J Cancer. 2006;42:437-45. https://doi.org/10.1016/j.ejca.2005.08.039.

4. Briscoe J, Therond PP. The mechanisms of Hedgehog signalling and its roles in development and disease. Nat Rev Mol Cell Biol. 2013;14:416-29. https://doi.org/10.1038/nrm3598.

5. Barakat MT, Humke EW, Scott MP. Learning from Jekyll to control Hyde: Hedgehog signaling in development and cancer. Trends Mol Med. 2010;16: 337-48. https://doi.org/10.1016/j.molmed.2010.05.003.

6. Ingham PW, MCMahon AP. Hedgehog signaling in animal development: paradigms and principles. Genes Dev. 2001;15:3059-87. https://doi.org/10. 1101/gad.938601.

7. Bangs F, Anderson KV. Primary Cilia and Mammalian Hedgehog Signaling Cold Spring Harb Perspect Biol. 2017;9. https://doi.org/10.1101/cshperspect. a028175.

8. Hui CC, Angers S. Gli proteins in development and disease. Annu Rev Cell Dev Biol. 2011;27:513-37. https://doi.org/10.1146/annurev-cellbio-092910154048

9. Byrne EF, Luchetti G, Rohatgi R, Siebold C. Multiple ligand binding sites regulate the Hedgehog signal transducer Smoothened in vertebrates. Curr Opin Cell Biol. 2018;51:81-8. https://doi.org/10.1016/j.ceb.2017.10.004.

10. Ruiz i Altaba A. Hedgehog signaling and the Gli code in stem cells, cancer, and metastases. Sci Signal. 2011;4:pt9. https://doi.org/10.1126/scisignal. 2002540.

11. Stecca B, Ruiz IAA. Context-dependent regulation of the GLI code in cancer by HEDGEHOG and non-HEDGEHOG signals. J Mol Cell Biol. 2010;2:84-95. https://doi.org/10.1093/jmcb/mjp052.

12. Teglund S, Toftgard R. Hedgehog beyond medulloblastoma and basal cell carcinoma. Biochim Biophys Acta. 1805;2010:181-208. https://doi.org/10. 1016/j.bbcan.2010.01.003.

13. Jiang J, Hui CC. Hedgehog signaling in development and cancer. Dev Cell. 2008;15:801-12. https://doi.org/10.1016/.jevcel.2008.11.010.

14. Beachy PA, Karhadkar SS, Berman DM. Tissue repair and stem cell renewal in carcinogenesis. Nature. 2004;432:324-31. https://doi.org/10.1038/ nature03100.

15. Raleigh DR, Reiter JF. Misactivation of Hedgehog signaling causes inherited and sporadic cancers. J Clin Invest. 2019;129:465-75. https://doi.org/10.1172/ jci120850.
16. Ruiz i Altaba A, Mas C, Stecca B. The Gli code: an information nexus regulating cell fate, stemness and cancer. Trends Cell Biol. 2007;17:438-47. https://doi.org/10.1016/j.tcb.2007.06.007.

17. Kasper M, Jaks V, Fiaschi M, Toftgard R. Hedgehog signalling in breast cancer. Carcinogenesis. 2009;30:903-11. https://doi.org/10.1093/carcin/ bgp048.

18. Kasper M, Jaks V, Hohl D, Toftgard R. Basal cell carcinoma - molecular biology and potential new therapies. J Clin Invest. 2012;122:455-63. https:// doi.org/10.1172/JCl58779.

19. Aberger F, Hutterer E, Sternberg C, Del Burgo PJ, Hartmann TN. Acute myeloid leukemia - strategies and challenges for targeting oncogenic Hedgehog/GLI signaling. Cell Commun Signal. 2017;15:8. https://doi.org/10. 1186/s12964-017-0163-4.

20. Aberger F, Kern D, Greil R, Hartmann TN. Canonical and noncanonical Hedgehog/GLI signaling in hematological malignancies. Vitam Horm. 2012; 88:25-54. https://doi.org/10.1016/B978-0-12-394622-5.00002-X.

21. Wessler S, Krisch LM, Elmer DP, Aberger F. From inflammation to gastric cancer - the importance of Hedgehog/GLI signaling in Helicobacter pyloriinduced chronic inflammatory and neoplastic diseases. Cell Commun Signal. 2017;15:15. https://doi.org/10.1186/s12964-017-0171-4.

22. McMillan R, Matsui W. Molecular pathways: the hedgehog signaling pathway in cancer. Clin Cancer Res. 2012;18:4883-8. https://doi.org/10.1158/ 1078-0432.CCR-11-2509.

23. LoRusso PM, Rudin CM, Reddy JC, Tibes R, Weiss GJ, Borad MJ, Hann CL, Brahmer JR, Chang I, Darbonne WC, Graham RA, Zerivitz KL, Low JA, Von Hoff DD. Phase I trial of hedgehog pathway inhibitor vismodegib (GDC0449) in patients with refractory, locally advanced or metastatic solid tumors. Clin Cancer Res. 2011;17:2502-11. https://doi.org/10.1158/10780432.CCR-10-2745.

24. Von Hoff DD, LoRusso PM, Rudin CM, Reddy JC, Yauch RL, Tibes R, Weiss GJ Borad MJ, Hann CL, Brahmer JR, Mackey HM, Lum BL, Darbonne WC, Marsters JC Jr, de Sauvage FJ, Low JA. Inhibition of the hedgehog pathway in advanced basal-cell carcinoma. N Engl J Med. 2009;361:1 164-72. https:// doi.org/10.1056/NEJMoa0905360

25. Dlugosz A, Agrawal S, Kirkpatrick P. Vismodegib. Nat Rev Drug Discov. 2012; 11:437-8. https://doi.org/10.1038/nrd3753.

26. Sekulic A, Migden MR, Oro AE, Dirix L, Lewis KD, Hainsworth JD, Solomon JA, Yoo S, Arron ST, Friedlander PA, Marmur E, Rudin CM, Chang AL, Low JA, Mackey HM, Yauch RL, Graham RA, Reddy JC, Hauschild A. Efficacy and safety of vismodegib in advanced basal-cell carcinoma. N Engl J Med. 2012; 366:2171-9. https://doi.org/10.1056/NEJMoa1113713.

27. Axelson M, Liu K, Jiang X, He K, Wang J, Zhao H, Kufrin D, Palmby T, Dong Z, Russell AM, Miksinski S, Keegan P, Pazdur R. U.S. Food and Drug Administration approval: vismodegib for recurrent, locally advanced, or metastatic basal cell carcinoma. Clin Cancer Res. 2013;19:2289-93. https:// doi.org/10.1158/1078-0432.ccr-12-1956.

28. Migden MR, Guminski A, Gutzmer R, Dirix L, Lewis KD, Combemale P, Herd RM, Kudchadkar R, Trefzer U, Gogov S, Pallaud C, Yi T, Mone M, Kaatz M, Loquai C, Stratigos AJ, Schulze HJ, Plummer R, Chang AL, Cornelis F, Lear JT, Sellami D, Dummer R. Treatment with two different doses of sonidegib in patients with locally advanced or metastatic basal cell carcinoma (BOLT): a multicentre, randomised, double-blind phase 2 trial. Lancet Oncol. 2015;16: 716-28. https://doi.org/10.1016/S1470-2045(15)70100-2.

29. Sekulic A, Von Hoff D. Hedgehog Pathway Inhibition. Cell. 2016;164:831. https://doi.org/10.1016/j.cell.2016.02.021.

30. Skvara H, Kalthoff F, Meingassner JG, Wolff-Winiski B, Aschauer H, Kelleher JF, Wu X, Pan S, Mickel L, Schuster C, Stary G, Jalili A, David OJ, Emotte C, Antunes AM, Rose K, Decker J, Carlson I, Gardner H, Stuetz A, Bertolino AP, Stingl G, De Rie MA. Topical treatment of Basal cell carcinomas in nevoid Basal cell carcinoma syndrome with a smoothened inhibitor. J Invest Dermatol. 2011;131:1735-44. https://doi.org/10.1038/jid.2011.48.

31. Casey D, Demko S, Shord S, Zhao H, Chen H, He K, Putman A, Helms W, Keegan P, Pazdur R. FDA Approval Summary: Sonidegib for Locally Advanced Basal Cell Carcinoma. Clin Cancer Res. 2017;23:2377-81. https:// doi.org/10.1158/1078-0432.ccr-16-2051.

32. Cortes JE, Heidel FH, Hellmann A, Fiedler W, Smith BD, Robak T, Montesinos P, Pollyea DA, DesJardins P, Ottmann O, Ma WW, Shaik MN, Laird AD, Zeremski M, O'Connell A, Chan G, Heuser M. Randomized comparison of low dose cytarabine with or without glasdegib in patients with newly diagnosed acute myeloid leukemia or high-risk myelodysplastic syndrome. Leukemia. 2019;33:379-89. https://doi.org/10.1038/s41375-018-0312-9. 
33. Norsworthy KJ, By K, Subramaniam S, Zhuang L, Del Valle PL, Przepiorka D, Shen YL, Sheth CM, Liu C, Leong R, Goldberg KB, Farrell AT, Pazdur R. FDA Approval Summary: Glasdegib for Newly Diagnosed Acute Myeloid Leukemia. Clin Cancer Res. 2019. https://doi.org/10.1158/1078-0432.CCR-19-0365.

34. Beauchamp EM, Ringer L, Bulut G, Sajwan KP, Hall MD, Lee YC, Peaceman D, Ozdemirli M, Rodriguez O, Macdonald TJ, Albanese C, Toretsky JA, Uren A. Arsenic trioxide inhibits human cancer cell growth and tumor development in mice by blocking Hedgehog/GLI pathway. J Clin Invest. 2011;121:148-60. https://doi.org/10.1172/jci42874.

35. Kim J, Lee JJ, Gardner D, Beachy PA. Arsenic antagonizes the Hedgehog pathway by preventing ciliary accumulation and reducing stability of the Gli2 transcriptional effector. Proc Natl Acad Sci U S A. 2010;107:13432-7. https://doi.org/10.1073/pnas.1006822107.

36. Tang JY, Mackay-Wiggan JM, Aszterbaum M, Yauch RL, Lindgren J, Chang K, Coppola C, Chanana AM, Marji J, Bickers DR, Epstein EH Jr. Inhibiting the hedgehog pathway in patients with the basal-cell nevus syndrome. N Engl J Med. 2012;366:2180-8. https://doi.org/10.1056/NEJMoa1113538.

37. Tang JY, Ally MS, Chanana AM, Mackay-Wiggan JM, Aszterbaum M, Lindgren JA, Ulerio G, Rezaee MR, Gildengorin G, Marji J, Clark C, Bickers DR, Epstein EH Jr. Inhibition of the hedgehog pathway in patients with basal-cell nevus syndrome: final results from the multicentre, randomised, double-blind, placebo-controlled, phase 2 trial. Lancet Oncol. 2016;17:1720-31. https://doi. org/10.1016/s1470-2045(16)30566-6.

38. Brinkhuizen $T$, Reinders MG, van Geel $M$, Hendriksen AJ, Paulussen AD, Winnepenninckx VJ, Keymeulen KB, Soetekouw PM, van Steensel MA, Mosterd K. Acquired resistance to the Hedgehog pathway inhibitor vismodegib due to smoothened mutations in treatment of locally advanced basal cell carcinoma. J Am Acad Dermatol. 2014;71:1005-8. https://doi.org/ 10.1016/j.jaad.2014.08.001.

39. Buonamici S, Williams J, Morrissey M, Wang A, Guo R, Vattay A, Hsiao K, Yuan J, Green J, Ospina B, Yu Q, Ostrom L, Fordjour P, Anderson DL, Monahan JE, Kelleher JF, Peukert S, Pan S, Wu X, Maira SM, Garcia-Echeverria C, Briggs KJ, Watkins DN, Yao YM, Lengauer C, Warmuth M, Sellers WR, Dorsch M. Interfering with resistance to smoothened antagonists by inhibition of the PI3K pathway in medulloblastoma. Sci Transl Med. 2010;2: 51-70. https://doi.org/10.1126/scitranslmed.3001599.

40. Atwood SX, Sarin KY, Whitson RJ, Li JR, Kim G, Rezaee M, Ally MS, Kim J, Yao C, Chang AL, Oro AE, Tang JY. Smoothened variants explain the majority of drug resistance in basal cell carcinoma. Cancer Cell. 2015;27:342-53. https:// doi.org/10.1016/j.ccell.2015.02.002.

41. Sharpe HJ, Pau G, Dijkgraaf GJ, Basset-Seguin N, Modrusan Z, Januario T, Tsui V, Durham AB, Dlugosz AA, Haverty PM, Bourgon R, Tang JY, Sarin KY, Dirix L, Fisher DC, Rudin CM, Sofen H, Migden MR, Yauch RL, de Sauvage FJ. Genomic analysis of smoothened inhibitor resistance in basal cell carcinoma. Cancer Cell. 2015;27:327-41. https://doi.org/10.1016/j.ccell.2015.02.001.

42. Atwood SX, Li M, Lee A, Tang JY, Oro AE. GLI activation by atypical protein kinase $C$ iota/lambda regulates the growth of basal cell carcinomas. Nature. 2013:494:484-8. https://doi.org/10.1038/nature11889.

43. Kuonen F, Huskey NE, Shankar G, Jaju P, Whitson RJ, Rieger KE, Atwood SX, Sarin KY, Oro AE. Loss of Primary Cilia Drives Switching from Hedgehog to Ras/MAPK Pathway in Resistant Basal Cell Carcinoma. J Invest Dermatol. 2019;139:1439-48. https://doi.org/10. 1016/j.jid.2018.11.035

44. Zhao X, Ponomaryov T, Ornell KJ, Zhou P, Dabral SK, Pak E, Li W, Atwood SX, Whitson RJ, Chang AL, Li J, Oro AE, Chan JA, Kelleher JF, Segal RA. RAS/ MAPK Activation Drives Resistance to Smo Inhibition, Metastasis, and Tumor Evolution in Shh Pathway-Dependent Tumors. Cancer Res. 2015;75:3623-35. https://doi.org/10.1158/0008-5472.CAN-14-2999-T.

45. Razumilava N, Gumucio DL, Samuelson LC, Shah YM, Nusrat A, Merchant JL. Indian Hedgehog Suppresses Intestinal Inflammation. Cell Mol Gastroenterol Hepatol. 2018;5:63-4. https://doi.org/10.1016/j.jcmgh.2017.10.003.

46. Zacharias WJ, Li X, Madison BB, Kretovich K, Kao JY, Merchant JL, Gumucio $\mathrm{DL}$. Hedgehog is an anti-inflammatory epithelial signal for the intestinal lamina propria. Gastroenterology. 2010;138:2368-77, 77 e1-4. https://doi. org/10.1053/j.gastro.2010.02.057.

47. Buongusto F, Bernardazzi C, Yoshimoto AN, Nanini HF, Coutinho RL, Carneiro AJV, Castelo-Branco MT, de Souza HS. Disruption of the Hedgehog signaling pathway in inflammatory bowel disease fosters chronic intestinal inflammation. Clin Exp Med. 2017;17:351-69. https://doi.org/10.1007/s10238-016-0434-1.

48. Kangwan N, Kim YJ, Han YM, Jeong M, Park JM, Go EJ, Hahm KB. Sonic hedgehog inhibitors prevent colitis-associated cancer via orchestrated mechanisms of IL-6/gp130 inhibition, 15-PGDH induction, Bcl-2 abrogation, and tumorsphere inhibition. Oncotarget. 2016;7:7667-82. https://doi.org/10. 18632/oncotarget.6765.

49. Lee JJ, Rothenberg ME, Seeley ES, Zimdahl B, Kawano S, Lu WJ, Shin K, Sakata-Kato T, Chen JK, Diehn M, Clarke MF, Beachy PA. Control of inflammation by stromal Hedgehog pathway activation restrains colitis. Proc Natl Acad Sci U S A. 2016;113:E7545-E53. https://doi.org/10.1073/pnas. 1616447113.

50. El-Zaatari M, Kao JY, Tessier A, Bai L, Hayes MM, Fontaine C, Eaton KA, Merchant JL. Gli1 deletion prevents Helicobacter-induced gastric metaplasia and expansion of myeloid cell subsets. PLoS One. 2013;8:e58935. https://doi. org/10.1371/journal.pone.0058935.

51. Holla S, Stephen-Victor E, Prakhar P, Sharma M, Saha C, Udupa V, Kaveri SV, Bayry J, Balaji KN. Mycobacteria-responsive sonic hedgehog signaling mediates programmed death-ligand 1- and prostaglandin E2-induced regulatory T cell expansion. Sci Rep. 2016;6:24193. https://doi.org/10.1038/srep24193.

52. Zhou X, Liu Z, Jang F, Xiang C, Li Y, He Y. Autocrine Sonic hedgehog attenuates inflammation in cerulein-induced acute pancreatitis in mice via upregulation of IL-10. PLoS One. 2012;7:e44121. https://doi.org/10.1371/ journal.pone.0044121.

53. Fan Q, Gu D, Liu H, Yang L, Zhang X, Yoder MC, Kaplan MH, Xie J. Defective TGF-beta signaling in bone marrow-derived cells prevents hedgehoginduced skin tumors. Cancer Res. 2014;74:471-83. https://doi.org/10.1158/ 0008-5472.CAN-13-2134-T.

54. Omland SH, Nielsen PS, Gjerdrum LM, Gniadecki R. Immunosuppressive Environment in Basal Cell Carcinoma: The Role of Regulatory T Cells. Acta Derm Venereol. 2016;96:917-21. https://doi.org/10.2340/00015555-2440.

55. Furler RL, Uittenbogaart CH. GLI2 regulates TGF-beta1 in human CD4+ T cells: implications in cancer and HIV pathogenesis. PLoS One. 2012;7:e40874. https://doi.org/10.1371/journal.pone.0040874.

56. Chakrabarti J, Holokai L, Syu L, Steele NG, Chang J, Wang J, Ahmed S, Dlugosz A, Zavros Y. Hedgehog signaling induces PD-L1 expression and tumor cell proliferation in gastric cancer. Oncotarget. 2018;9:37439-57. https://doi.org/10.18632/oncotarget.26473.

57. Ng JM, Curran T. The Hedgehog's tale: developing strategies for targeting cancer. Nat Rev Cancer. 2011;11:493-501. https://doi.org/10.1038/nrc3079.

58. Chen DS, Mellman I. Oncology meets immunology: the cancer-immunity cycle. Immunity. 2013;39:1-10. https://doi.org/10.1016/j.immuni.2013.07.012.

59. Pardoll D, Allison J. Cancer immunotherapy: breaking the barriers to harvest the crop. Nat Med. 2004;10:887-92. https://doi.org/10.1038/nm0904-887.

60. Wei SC, Duffy CR, Allison JP. Fundamental Mechanisms of Immune Checkpoint Blockade Therapy. Cancer Discov. 2018;8:1069-86. https://doi. org/10.1158/2159-8290.CD-18-0367.

61. Okazaki T, Chikuma S, Iwai Y, Fagarasan S, Honjo T. A rheostat for immune responses: the unique properties of PD-1 and their advantages for clinical application. Nat Immunol. 2013;14:1212-8. https://doi.org/10.1038/ni.2762.

62. Bonilla X, Parmentier L, King B, Bezrukov F, Kaya G, Zoete V, Seplyarskiy VB, Sharpe HJ, McKee T, Letourneau A, Ribaux PG, Popadin K, Basset-Seguin N, Ben Chaabene R, Santoni FA, Andrianova MA, Guipponi M, Garieri M, Verdan C, Grosdemange K, Sumara O, Eilers M, Aifantis I, Michielin O, de Sauvage FJ, Antonarakis SE, Nikolaev SI. Genomic analysis identifies new drivers and progression pathways in skin basal cell carcinoma. Nat Genet. 2016;48:398406. https://doi.org/10.1038/ng.3525.

63. Fan Q, He M, Sheng T, Zhang X, Sinha M, Luxon B, Zhao X, Xie J. Requirement of TGFbeta signaling for SMO-mediated carcinogenesis. J Biol Chem. 2010;285:36570-6. https://doi.org/10.1074/jbc.C110.164442.

64. Hanna A, Metge BJ, Bailey SK, Chen D, Chandrashekar DS, Varambally S, Samant RS, Shevde LA. Inhibition of Hedgehog signaling reprograms the dysfunctional immune microenvironment in breast cancer. Oncoimmunology. 2019;8:1548241. https://doi.org/10.1080/2162402X.2018.1548241.

65. Furmanski AL, Barbarulo A, Solanki A, Lau Cl, Sahni H, Saldana JI, D'Acquisto F, Crompton T. The transcriptional activator Gli2 modulates T-cell receptor signalling through attenuation of AP-1 and NFkappaB activity. J Cell Sci. 2015;128:2085-95. https://doi.org/10.1242/jcs.165803.

66. Yanez DC, Lau Cl, Chawda MM, Ross S, Furmanski AL, Crompton T. Hedgehog signalling promotes Th2 differentiation in naive human CD4 T cells. J Allergy Clin Immunol. 2019. https://doi.org/10.1016/j.jaci.2019.07.011, https://doi.org/10.1016/j.jaci.2019.07.011.

67. Furmanski AL, Saldana Jl, Ono M, Sahni H, Paschalidis N, D'Acquisto F, Crompton T. Tissue-derived hedgehog proteins modulate Th differentiation and disease. J Immunol. 2013;190:2641-9. https://doi.org/10.4049/jimmunol.1202541. 
68. Papaioannou E, Yanez DC, Ross S, Lau Cl, Solanki A, Chawda MM, Virasami A, Ranz I, Ono M, O'Shaughnessy RFL, Crompton T. Sonic Hedgehog signaling limits atopic dermatitis via Gli2-driven immune regulation. J Clin Invest. 2019:129:3153-70. https://doi.org/10.1172/JCI125170.

69. Westendorp BF, Buller N, Karpus ON, van Dop WA, Koster J, Versteeg R, Koelink PJ, Snel CY, Meisner S, Roelofs J, Uhmann A, Ver Loren van Themaat E, Heijmans J, Hahn H, Muncan V, Wildenberg ME, van den Brink GR. Indian Hedgehog Suppresses a Stromal Cell-Driven Intestinal Immune Response. Cell Mol Gastroenterol Hepatol. 2018;5:67-82.e1. https://doi.org/10.1016/j. jcmgh.2017.08.004.

70. Schumacher MA, Feng R, Aihara E, Engevik AC, Montrose MH, Ottemann KM, Zavros Y. Helicobacter pylori-induced Sonic Hedgehog expression is regulated by NFkappaB pathway activation: the use of a novel in vitro model to study epithelial response to infection. Helicobacter. 2015;20:19-28. https://doi.org/10.1111/hel.12152.

71. Ding L, Hayes MM, Photenhauer A, Eaton KA, Li Q, Ocadiz-Ruiz R, Merchant $J$ L. Schlafen 4-expressing myeloid-derived suppressor cells are induced during murine gastric metaplasia. J Clin Invest. 2016;126:2867-80. https:// doi.org/10.1172/jci82529.

72. Schumacher MA, Donnelly JM, Engevik AC, Xiao C, Yang L, Kenny S, Varro A, Hollande F, Samuelson LC, Zavros Y. Gastric Sonic Hedgehog acts as a macrophage chemoattractant during the immune response to Helicobacter pylori. Gastroenterology. 2012;142:1150-9.e6. https://doi.org/10.1053/j.gastro. 2012.01.029.

73. Merchant JL, Ding L. Hedgehog Signaling Links Chronic Inflammation to Gastric Cancer Precursor Lesions. Cell Mol Gastroenterol Hepatol. 2017;3: 201-10. https://doi.org/10.1016/j.jcmgh.2017.01.004.

74. Fischer S, Ali OH, Jochum W, Kluckert T, Flatz L, Siano M. Anti-PD-1 Therapy Leads to Near-Complete Remission in a Patient with Metastatic Basal Cell Carcinoma. Oncol Res Treat. 2018:41:391-4. https://doi.org/10.1159/ 000487084.

75. Ikeda S, Goodman AM, Cohen PR, Jensen TJ, Ellison CK, Frampton G, Miller $V$, Patel SP, Kurzrock R. Metastatic basal cell carcinoma with amplification of PD-L1: exceptional response to anti-PD1 therapy. NPJ Genom Med. 2016;1. https://doi.org/10.1038/npjgenmed.2016.37.

76. Lipson EJ, Lilo MT, Ogurtsova A, Esandrio J, Xu H, Brothers P, Schollenberger M, Sharfman WH, Taube JM. Basal cell carcinoma: PD-L1/PD-1 checkpoint expression and tumor regression after PD-1 blockade. J Immunother Cancer. 2017;5:23. https://doi.org/10.1186/s40425-017-0228-3.

77. Martin AM, Nirschl CJ, Polanczyk MJ, Bell WR, Nirschl TR, Harris-Bookman S, Phallen J, Hicks J, Martinez D, Ogurtsova A, Xu H, Sullivan LM, Meeker AK, Raabe EH, Cohen KJ, Eberhart CG, Burger PC, Santi M, Taube JM, Pardoll DM, Drake CG, Lim M. PD-L1 expression in medulloblastoma: an evaluation by subgroup. Oncotarget. 2018;9:19177-91. https://doi.org/10.18632/ oncotarget.24951.

78. Chambers WH, Rabinowich H, Herberman RB. Mechanisms of Immunosuppression. 2003, https://www.ncbi.nlm.nih.gov/books/NBK12565/.

79. Otsuka A, Dreier J, Cheng PF, Nageli M, Lehmann H, Felderer L, Frew IJ, Matsushita S, Levesque MP, Dummer R. Hedgehog pathway inhibitors promote adaptive immune responses in basal cell carcinoma. Clin Cancer Res. 2015;21:1289-97. https://doi.org/10.1158/ 1078-0432.CCR-14-2110.

80. Hanahan D, Weinberg RA. Hallmarks of cancer: the next generation. Cell. 2011;144:646-74. https://doi.org/10.1016/j.cell.2011.02.013.

81. Mantovani A, Allavena P, Sica A, Balkwill F. Cancer-related inflammation. Nature. 2008;454:436-44. https://doi.org/10.1038/ nature07205.

82. Grivennikov SI, Greten FR, Karin M. Immunity, inflammation, and cancer. Cell. 2010;140:883-99. https://doi.org/10.1016/j.cell.2010.01.025

83. Landskron G, De la Fuente M, Thuwajit P, Thuwajit C, Hermoso MA. Chronic inflammation and cytokines in the tumor microenvironment. J Immunol Res. 2014;2014:149185. https://doi.org/10.1155/2014/149185.

84. Mills LD, Zhang Y, Marler RJ, Herreros-Villanueva M, Zhang L, Almada LL, Couch F, Wetmore C, Pasca di Magliano M, Fernandez-Zapico ME. Loss of the transcription factor GLI1 identifies a signaling network in the tumor microenvironment mediating KRAS oncogene-induced transformation. J Biol Chem. 2013;288:11786-94. https://doi.org/10.1074/jbc.M112.438846.

85. Wang $Y$, Jin G, Li Q, Wang Z, Hu W, Li P, Li S, Wu H, Kong X, Gao J, Li Z. Hedgehog Signaling Non-Canonical Activated by ProInflammatory Cytokines in Pancreatic Ductal Adenocarcinoma. J Cancer. 2016;7:2067-76. https://doi.org/10.7150/jca.15786.
86. Nakashima H, Nakamura M, Yamaguchi H, Yamanaka N, Akiyoshi T, Koga K, Yamaguchi K, Tsuneyoshi M, Tanaka M, Katano M. Nuclear factor-kappaB contributes to hedgehog signaling pathway activation through sonic hedgehog induction in pancreatic cancer. Cancer Res. 2006;66:7041-9. https://doi.org/10.1158/0008-5472.CAN-05-4588.

87. Sternberg C, Gruber W, Eberl M, Tesanovic S, Stadler M, Elmer DP, Schlederer M, Grund S, Roos S, Wolff F, Kaur S, Mangelberger D, Lehrach $H$, Hache $H$, Wierling C, Laimer J, Lackner P, Wiederstein M, Kasper M, Risch A, Petzelbauer P, Moriggl R, Kenner L, Aberger F. Synergistic cross-talk of hedgehog and interleukin- 6 signaling drives growth of basal cell carcinoma. Int J Cancer. 2018;143:2943-54. https://doi.org/10.1002/ijc.31724.

88. Gu D, Fan Q, Zhang X, Xie J. A role for transcription factor STAT3 signaling in oncogene smoothened-driven carcinogenesis. J Biol Chem. 2012;287: 38356-66. https://doi.org/10.1074/jbc.M112.377382.

89. Moreira A, Kirchberger MC, Toussaint F, Erdmann M, Schuler G, Heinzerling L. Effective anti-programmed death-1 therapy in a SUFU-mutated patient with Gorlin-Goltz syndrome. Br J Dermatol. 2018;179:747-9. https://doi.org/ 10.1111/bjd.16607.

90. Chang ALS, Tran DC, Cannon JGD, Li S, Jeng M, Patel R, Van der Bokke $L$, Pague A, Brotherton R, Rieger KE, Satpathy AT, Yost KE, Reddy $S$, Sarin K, Colevas AD. Pembrolizumab for advanced basal cell carcinoma: An investigator-initiated, proof-of-concept study. J Am Acad Dermatol. 2019;80:564-6. https://doi.org/10.1016/j.jaad.2018.08.017.

91. Gerling M, Buller NV, Kirn LM, Joost S, Frings O, Englert B, Bergstrom A, Kuiper RV, Blaas L, Wielenga MC, Almer S, Kuhl AA, Fredlund E, van den Brink GR, Toftgard R. Stromal Hedgehog signalling is downregulated in colon cancer and its restoration restrains tumour growth. Nat Commun. 2016;7:12321. https://doi.org/10.1038/ncomms12321.

92. Samstein RM, Lee $C H$, Shoushtari AN, Hellmann MD, Shen $R$, Janjigian YY, Barron DA, Zehir A, Jordan EJ, Omuro A, Kaley TJ, Kendall SM, Motzer RJ, Hakimi AA, Voss MH, Russo P, Rosenberg J, lyer G, Bochner BH, Bajorin DF, Al-Ahmadie HA, Chaft JE, Rudin CM, Riely GJ, Baxi S, Ho AL, Wong RJ, Pfister DG, Wolchok JD, Barker CA, Gutin PH, Brennan CW, Tabar V, Mellinghoff IK, DeAngelis LM, Ariyan CE, Lee N, Tap WD, Gounder MM, D'Angelo SP, Saltz L, Stadler ZK, Scher HI, Baselga J, Razavi P, Klebanoff CA, Yaeger R, Segal NH, Ku GY, DeMatteo RP, Ladanyi M, Rizvi NA, Berger MF, Riaz N, Solit DB, Chan TA, Morris LGT. Tumor mutational load predicts survival after immunotherapy across multiple cancer types. Nat Genet. 2019;51:2026. https://doi.org/10.1038/s41588-018-0312-8.

93. Papakostas D, Stockfleth E. Topical treatment of basal cell carcinoma with the immune response modifier imiquimod. Future Oncol. 2015;11:2985-90. https://doi.org/10.2217/fon.15.192.

94. Huang SJ, Hijnen D, Murphy GF, Kupper TS, Calarese AW, Mollet IG, Schanbacher CF, Miller DM, Schmults CD, Clark RA. Imiquimod enhances IFN-gamma production and effector function of $\mathrm{T}$ cells infiltrating human squamous cell carcinomas of the skin. J Invest Dermatol. 2009;129:2676-85. https://doi.org/10.1038/jid.2009.151.

95. Drobits B, Holcmann M, Amberg N, Swiecki M, Grundtner R, Hammer M, Colonna M, Sibilia M. Imiquimod clears tumors in mice independent of adaptive immunity by converting pDCs into tumor-killing effector cells. J Clin Invest. 2012;122:575-85. https://doi.org/10.1172/JCl61034.

96. Gruber W, Frischauf AM, Aberger F. An old friend with new skills: Imiquimod as novel inhibitor of Hedgehog signaling in basal cell carcinoma. Oncoscience. 2014;1:567-73. https://doi.org/10.18632/oncoscience.80.

97. Wolff F, Loipetzberger A, Gruber W, Esterbauer H, Aberger F, Frischauf AM. Imiquimod directly inhibits Hedgehog signalling by stimulating adenosine receptor/protein kinase A-mediated GLI phosphorylation. Oncogene. 2013; 32:5574-81. https://doi.org/10.1038/onc.2013.343.

98. de la Roche M, Ritter AT, Angus KL, Dinsmore C, Earnshaw CH, Reiter JF, Griffiths GM. Hedgehog signaling controls T cell killing at the immunological synapse. Science. 2013;342:1247-50. https://doi.org/10.1126/ science.1244689.

99. Curran T. Reproducibility of academic preclinical translational research: lessons from the development of Hedgehog pathway inhibitors to treat cancer. Open Biol. 2018;8. https://doi.org/10.1098/rsob.180098.

\section{Publisher's Note}

Springer Nature remains neutral with regard to jurisdictional claims in published maps and institutional affiliations. 